\title{
THE INHIBITORY EFFECTS OF THIAZOLYL-2,4- THIAZOLIDINEDIONE COMPOUNDS ON THE RAT KIDNEY ALDOSE REDUCTASE ENZYME
}

\author{
TIYAZOLIL-2,4-TIYAZOLIDINDION BILESŞIKLERININ RAT BÖBREK ALDOZ \\ REDÜKTAZ ENZIMI ÜZERINNDEKİ İNHIBITÖR ETKILERİ
}

\section{Meltem CEYLAN ÜNLÜSOY ${ }^{1}$, Net DAŞ EVCIMEN ${ }^{2 *}$, Mutlu SARIKAYA ${ }^{2}$, Oya BOZDAĞ DÜNDAR ${ }^{1}$, Rahmiye ERTAN ${ }^{1}$}

${ }^{1}$ Ankara University, Faculty of Pharmacy, Department of Pharmaceutical Chemistry, 06100, Tandoğan, Ankara - TURKEY

${ }^{2}$ Ankara University, Faculty of Pharmacy, Department of Biochemistry, 06100

Tandoğan, Ankara - TURKEY

\begin{abstract}
Aldose reductase enzyme is the key factor in the reduction of glucose to sorbitol. Accumulation of sorbitol in diabetes causes complications such as diabetic cataract, retinopathy, neuropathy and nephropathy. Aldose reductase inhibitors have been found to prevent sorbitol accumulation in tissues. Numerous compounds have been prepared in order to improve the pharmacological profile of inhibition of aldose reductase enzyme. In this study, series of thiazolyl-2,4-thiazolidinediones (Ia-f, IIa-f and IIIa-f) were tested for their aldose reductase inhibitory activities. It was found that substituted-thiazolyl-thiazolidinedione derivatives showing very slight inhibitor activity.
\end{abstract}

Key words: 2,4-Thiazolidinediones, Thiazole derivatives, Aldose reductase enzyme, Inhibition, Diabetes.

*Correspondence: e-mail: nevcimen@ankara.edu.tr Tel no: +90(312)2033037, Fax no: + 90(312)2131081 
ÖZET

Aldoz redüktaz enzimi glukozun sorbitole indirgenmesi reaksiyonunda anahtar rol oynamaktadır. Sorbitolün birikimi diyabette, diyabetik katarakt, retinopati, nöropati ve nefropati gibi komplikasyonlara neden olmaktadır. Aldoz redüktaz inhibitörlerinin dokularda sorbitol birikimini önlediği gösterilmiştir. Aldoz redüktaz enziminin inhibisyonunun farmakolojik profilini geliştirmek amacı ile çok sayıda bileşik geliştirilmiştir. Bu çalışmada, tiyazolil-2,4-tiyazolidindion serilerinin (Ia-f, IIa-f and IIIa-f) aldoz redüktaz inhibitör aktiviteleri test edilmiştir. Substitüe-tiyazolil-tiyazolidindion türevlerinin çok az düzeyde inhibitör aktiviteleri olduğu tespit edilmiştir.

Anahtar kelimeler: 2,4-Tiyazolidindionlar, Tiyazol Türevleri, Aldoz Redüktaz Enzimi, İnhibisyon, Diyabet

\section{INTRODUCTION}

Diabetic complications are the major cause of morbidity and mortality in patients with type 1 and type 2 diabetes. Chronic hyperglycemia is a major initiator factor of microvascular complications of diabetes (retinopathy, neuropathy, and nephropathy). Besides microvascular complications, cataracts and atherogenesis may also occur in diabetes (1).

The sorbitol pathway is a minor pathway of glucose metabolism in most tissues under normal conditions. The sorbitol pathyway consist of two dehydrogenases, aldose reductase (AR) and sorbitol dehydrogenases (Figure 1).

In mammals aldose reductase enzyme has low affinity to glucose, the conversion of glucose to sorbitol is less catalyzed. However, in diabetes mellitus certain tissues are subject to exposure to high glucose levels. Elevation of intracellular glucose levels can cause an increased flux through the enzyme AR, which is only activated when glucose concentrations rise to hyperglycemic levels. AR uses NADPH to reduce glucose to sorbitol which is then oxidized to fructose via sorbitol deydrogenase (which uses $\mathrm{NAD}^{+}$as a cofactor). Due to a high level of expression of AR in the lens compared to other tissues an increased level of sorbitol is felt to contribute to the development of cataract (1). Increased sorbitol dehydrogenase activity also involves in the diabetic complications (Figure 1). 


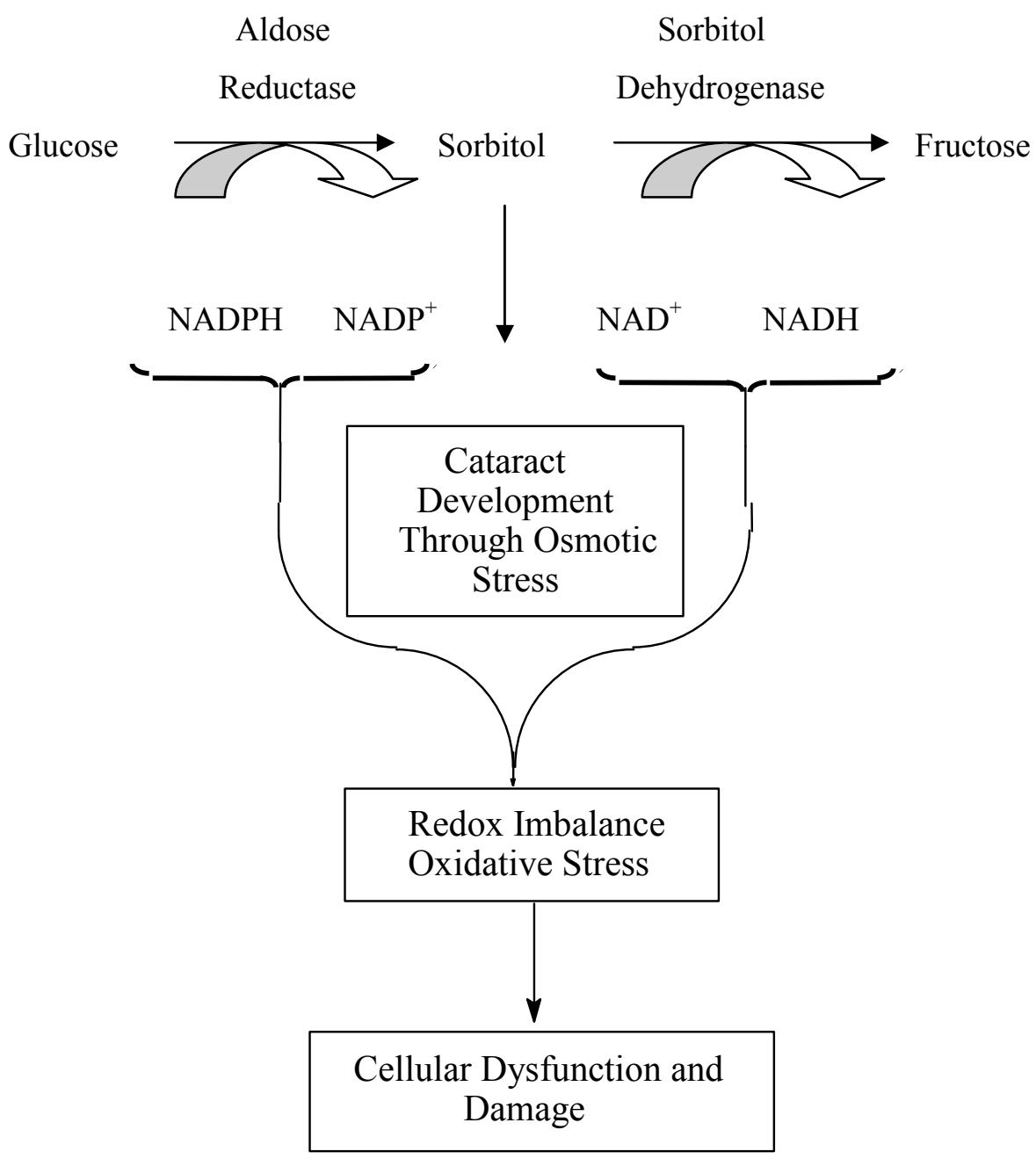

Figure 1. The aldose reductase (AR) pathway theory. $\mathrm{NAD}^{+}=$oxidized nicotinamide adenine dinucleotide; $\mathrm{NADH}=$ reduced nicotinamide adenine dinucleotide; $\mathrm{NADP}^{+}=$oxidized nicotinamide adenine dinucleotide phosphate; NADPH = reduced nicotinamide adenine dinucleotide phosphate.

As a result of faster rate of sorbitol formation than its conversion to fructose, and also the polarity of the sorbitol prevents it from exiting the cell, accumulations of sorbitol in diabetic subjects cause and/or are associated with diabetic complications including those of a lenticular, retinal, neuronal and renal nature.

Although intracellular sorbitol has been postulated to cause osmotic vascular damage (2), it is difficult to rationalize this possibility since intracellular levels of sorbitol in vascular cells are in the nanomolar range compared to the micro- and even millimolar range for other metabolites of glucose in these cells (3). 
The reduction of NADPH levels in cells caused by increases in AR flux may decrease the generation of nitric oxide (NO) in endothelial cells (4) and alter the cellular redox balance (Figure 1).

Enzyme inhibitors are molecular agents that interfere with catalysis, slowing or halting enzymatic reactions. The study of enzyme inhibitors also has provided valuable information about enzyme mechanisms and has helped define some metabolic pathways.

Aldose reductase inhibitors (ARIs) have been shown to reduce tissue sorbitol accumulation in diabetic animals (5). Studies have shown evidence which provides support for a major role for $\mathrm{AR}$ in the manifestations of various diabetic complications and it has become apparent that inhibitors of aldose reductase enzyme may be able to prevent, retard, or reverse the complications of chronic diabetes $(6,7,8,9,10,11)$. A number of inhibitors have been developed to the stage of clinical evaluation, some problems of lack of effect and adverse reactions have been encountered (12).

Aldose reductase inhibitors (Figure 2) can be grouped into two chemical classes: hydantoins (such as sorbinil) and carboxylic acids (such as epalrestat, tolrestat) (5). Nevertheless, many of them have shown to be clinically inadequate because of adverse pharmacokinetics or toxic sideeffects (13). At present, epalrestat is the only ARI available on the market (5).

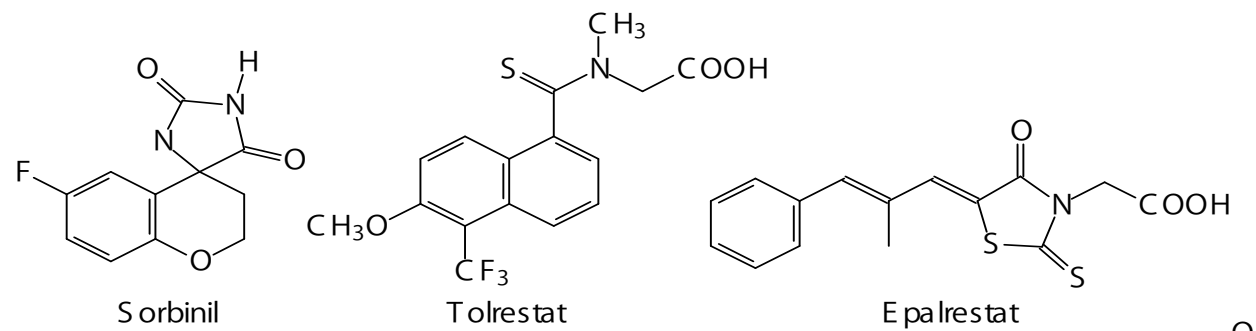<smiles>CCc1ccc(CCOc2ccc(CC3SC(=O)N(I)C3=O)cc2)nc1</smiles><smiles>[X]c1ccc(CN2C(=O)S/C(=C\c3sc([R])nc3Cl)C2=O)c([Y4])c1</smiles><smiles>[R]#CSCc1ccccc1</smiles>

$\mathrm{X}=\mathrm{H}, \mathrm{F}, \mathrm{Cl}, \mathrm{Br}, \mathrm{NO}_{2}, \mathrm{X}_{1}=\mathrm{H}, \mathrm{Cl}$

IIIa-f $R=$<smiles>COc1ccc(CSC)cc1</smiles>

Figure 2. Formula of the compounds 
2,4-Thiazolidinediones (2,4-TZDs) are a new class of antidiabetic agents which are effective in normalizing glucose and lipid metabolism associated with insulin resistance (14). Several new 2,4-TZDs such as pioglitazone, rosiglitazone (Figure 2) have been marketed for the treatment of type 2 diabetes $(15,16)$ and in the prevention of its late complications. 2,4-TZDs can be viewed as hydantoin bioisosters potentially free of the hypersensitivity reactions which are linked to the presence of the hydantoin system $(5,17)$.

In our previous study, the synthesis and insulinotropic activity in INS-1 cells evaluation of thiazolyl-2,4-TZD derivatives have been described. A significant insulinotropic effect was seen with some of the compounds (18). It was reported that some 2,4-thiazolidinediones have been patented as antihyperglycemic and ALR2 inhibitory agents with dual activity $(5,17)$.

In this study, we have determined the probable inhibitory effects of some thiazolyl-2,4-TZD derivatives, already known to have antidiabetic activities, on rat kidney homogenates.

\section{MATERIALS AND METHODS}

\section{Chemistry}

The compounds Ia-f, IIa-f and IIIa-f (Fig. 2) were synthesized by Knoevenagel reaction of substituted benzyl-2,4-thiazolidinediones with chlorothiazolecarbaldehydes (I, II and III) (18). All reagents were purchased from E. Merck (Darmstadt, Germany) and Aldrich (Milwaukee, MI, USA).

\section{Biological activity studies}

\section{Animals}

Male Albino rats weighing 200-250 g were used for experiments. They received standart diet. 30 rats were sacrified and kidney tissues were obtained. Aldose reductase activity was determined after isolation from kidney tissue. All the enzyme experiments were performed triplicate. Procedures involving the animals and their care conformed to institutional guidelines, in compliance with national and international laws and guidelines for the use of animals in biomedical research.

\section{Isolation of aldose reductase enzyme}

The aldose reductase enzyme was isolated by a method described below. 30 pooled kidney which were obtained from 200-250 g albino rats, were thawed on ice and homogenized with 3 volume of distilled water, followed by centrifugation at $10000 \mathrm{x}$ g for 20 minutes. Saturated ammonium sulfate was added to the supernatant to $40 \%$ saturation. The thick suspension had been stirred for 15 minutes, followed by centrifugation at $10000 \mathrm{x}$ g for 20 minutes. The inert protein left 
in the supernatant was remowed by increasing the ammonium sulfate concentration to $50 \%$ saturation followed by centrifuging the mixture at $10000 \mathrm{x}$ g for 20 minutes. The aldose reductase enzyme was precipitated from the $50 \%$ saturated solution by adding powdered ammonuim sulfate to $75 \%$ saturation and was recovered by centrifugation at $10000 \mathrm{x}$ g for 20 minutes. Protein concentration was measured by the method of Bradford (19) using bovine serum as the standard.

\section{Determination of aldose reductase activity}

Aldose reductase activity of the freshly prepared supernatant was assayed spectrophotometrically by determining the decrease in NADPH concentration at $340 \mathrm{~nm}$ by a UV1700 Visible spectrophotometer. DL-glyceraldehyde was used as the substrate. The enzyme was dissolved in $10 \mathrm{ml} 0,05 \mathrm{M} \mathrm{NaCI}$ solution and $0,1 \mathrm{ml}$ was added to a quartz cuvette containing 0,1 $\mathrm{ml}$ phosphate buffer $(0,067 \mathrm{M}, \mathrm{pH}: 6,2), 0,1 \mathrm{ml} \mathrm{NADPH}\left(2 \times 10^{-5} \mathrm{M}\right.$ final concentration), $0,1 \mathrm{ml}$ of the test drug (a 10-4 M solutions prepared in 50\% DMF and 50\% Metanol ) and 2,4 ml distilled water to obtain $2,9 \mathrm{ml}$ solution. The reaction is started by the adding of $0,1 \mathrm{ml}$ DL-glyceraldehyde $\left(5 \times 10^{-5} \mathrm{M}\right.$ final concentration ) to the cuvette and the decrease in NADPH concentration was recorder at $340 \mathrm{~nm}$ for 5 minutes at $37{ }^{\circ} \mathrm{C}$. Reading was taken at intervals in the periods when the changes in absorbance were linear (20).

\section{RESULTS AND DISCUSSION}

In this study, the aldose reductase inhibitory effects of the thiazolyl-2,4-TZDs (Ia-f, IIa-f, IIIa-f) which has significant insulinotropic effect (18), were determined by using rat kidney homogenates. On the basis of these biological results, we tried to identify whether these compounds has ARI activity besides antihyperglycemic effect.

The inhibition obtained by TZD derivatives was studied in vitro and the results are represented in Table 1. The enzyme activity was assayed by spectrophotometrically monitoring NADPH oxidation which accompanies the reduction of D-L-glyceraldehyde used as substrate. The inhibition study was performed merely by using a $10^{-4} \mathrm{M}$ concentration of each drug.

It was found that compounds Ia-f, IIa-f, IIIa-f showed very weak inhibitory effect. Surprisingly, the thiazol ring which has different substitutents (such as chloride, benzyl thio and pmethoxy-benzyl thio) at C-2 position did not show significant inhibitory activity (Table 1).

It has been proposed that three regions might be responsible on the AR for the interaction with drugs: a substrat site, a nucleotide fold, and an inhibitor site (21). It was reported that compounds possessed the essential structural requisites (an acidic proton, hydrogen-bond acceptor groups and an aromatic moiety) for aldose reductase inhibitory effect, in accordance with known pharmacophoric requirements $(22,23)$. An aromatic ring with the capability of hydrogen bonding ability also required to afford AR inhibitory activity. 
In our study, the probable reason of the unsignificant inhibitory effect of the TZD derivatives may be the effect of the thiazole ring having chloride, benzyl thio and p-methoxy-benzyl thio substituents at C-5 position of the TZD ring. They may be prevented the enzyme drug interaction at the inhibitor site of the enzyme. The aromatic ring might not have the capability of hidrojen bonding ability with the enzyme.

Table 1. Aldose reductase inhibition by compounds Ia-f, IIa-f and IIIa-f*<smiles>[X]c1ccc(CN2C(=O)S/C(=C\c3sc([R])nc3Cl)C2=O)c([Y])c1</smiles>

\begin{tabular}{|c|c|c|c|c|}
\hline Compounds & $\mathbf{R}$ & $\mathbf{X}$ & $\mathbf{X}_{1}$ & Inhibition (\%) \\
\hline Ia & $\mathrm{Cl}$ & $\mathrm{H}$ & $\mathrm{H}$ & $7,00 \pm 6,94$ \\
\hline Ib & $\mathrm{Cl}$ & $\mathrm{F}$ & $\mathrm{H}$ & $3,42 \pm 5,11$ \\
\hline Ic & $\mathrm{Cl}$ & $\mathrm{Cl}$ & $\mathrm{H}$ & $0,00 \pm 0,00$ \\
\hline Id & $\mathrm{Cl}$ & $\mathrm{Br}$ & $\mathrm{H}$ & $1,09 \pm 2,10$ \\
\hline Ie & $\mathrm{Cl}$ & $\mathrm{Cl}$ & $\mathrm{Cl}$ & $3,42 \pm 4,43$ \\
\hline If & $\mathrm{Cl}$ & $\mathrm{NO}_{2}$ & $\mathrm{H}$ & \\
\hline IIa & & $\mathrm{H}$ & $\mathrm{H}$ & $6,07 \pm 8,20$ \\
\hline IIb & & $\mathrm{F}$ & $\mathrm{H}$ & $0,00 \pm 0,00$ \\
\hline IIc & & $\mathrm{Cl}$ & $\mathrm{H}$ & $0,00 \pm 0,00$ \\
\hline IId & & $\mathrm{Br}$ & $\mathrm{H}$ & $1,09 \pm 3,50$ \\
\hline IIe & & $\mathrm{Cl}$ & $\mathrm{Cl}$ & $0,00 \pm 0,00$ \\
\hline IIf & & $\mathrm{NO}_{2}$ & $\mathrm{H}$ & $3,73 \pm 8,29$ \\
\hline IIIa & & $\mathrm{H}$ & $\mathrm{H}$ & $0,00 \pm 0,00$ \\
\hline IIIb & & $\mathrm{F}$ & $\mathrm{H}$ & $1,87 \pm 12,63$ \\
\hline IIIC & & $\mathrm{Cl}$ & $\mathrm{H}$ & $0,00 \pm 0,00$ \\
\hline IIId & & $\mathrm{Br}$ & $\mathrm{H}$ & $4,36 \pm 0,84$ \\
\hline IIIe & & $\mathrm{Cl}$ & $\mathrm{Cl}$ & $7,47 \pm 1,46$ \\
\hline IIIf & & $\mathrm{NO}_{2}$ & $\mathrm{H}$ & $0,94 \pm 3,54$ \\
\hline
\end{tabular}

*Values represent the mean \pm S. D. of three individual experiments. 
On the other hand, formation of a covalent link between an enzyme and inhibitor complex also needs acidic proton group besides aromatic ring. Therefore, other probable reason of the weak inhibitory effect of compounds might also depend on having the benzyl group instead of the acidic proton in N-3 position of the TZD ring.

Acknowledgement: This work was supported by Research Organization of Ankara University, Turkey (No: 2005-0803048).

\section{REFERENCES}

1- Kinoshita J.H. "Cataracts in galactosemia" Invest. Ophthalmol. Vis. Sci., 13, 713-24 (1974).

2- Gabbay K.H. "Hyperglycemia, polyol metabolism and complications of diabetes mellitus" Annu. Rev. Med., 26, 521-36 (1975).

3- Van Den Eden M.K., Nyengaard J.R., Ostrow E., Burgan J.H., Williamson J.R. "Elevated glucose levels increase retinal glycolysis and sorbitol pathway metabolism. Implications for diabetic retinopathy" Invest. Ophthalmol. Vis. Sci., 36, 1675-85 (1995).

4- Tesfamamriam B. "Free radicals in diabetic endothelial cell dysfunction" Free Rad. Biol. Med., 16, 383-91 (1994).

5- Costantino L., Rastelli G., Gamberoni M.C., Barlocco D. "Pharmacological approaches to the treatment of diabetic complications" Exp. Opin. Ther. Pat., 10, 1245-62 (2000).

6- Yue D.K., Hanwell M.A., Satchell P.M., Turtle J.R. "The effect of aldose reductase inhibition on motor nerve conduction velocity in diabetic rats" Diabetes, 31 (9), 789-94 (1982).

7- Kador F.P., Kinoshita J.H., Sharpless N.E. "Aldose reductase inhibitors: a potential new class of agents for the pharmacological control of certain diabetic complications" J. Med. Chem., 28, 841-49 (1985).

8- Kador P.F., Akagi Y., Takahashi Y., Ikebe H., Wyman M., Kinoshita J.H. "Prevention of retinal vessel changes associated with diabetic retinopathy in galactose-fed dogs by aldose reductase inhibitors" Arch. Ophthalmol., 108, 1301-09 (1990).

9- Cameron N.E., Leonard M.B., Ross I.S., Whiting P.H. "The effects of sorbinil on peripheral nevre conduction velocity, polyol concentrations and morphology in the streptozotocin-diabetic rat" Diabetologia, 29, 168-74 (1986). 
10- Mauer S.M., Steffes M.W., Azar S., Brown D.M. "Effects of sorbinil on glomerular structure and function in long-term-diabetic rats" Diabetes, 38 (7), 839-46 (1989).

11- Robison W.G. Jr, Nagata M., Laver N., Hohman T.C., Kinoshita J.H. "Diabetic-like retinopathy in rats prevented with an aldose reductase inhibitör" Invest. Ophthalmol. Vis. Sci., 30 (11), 2285-92 (1989).

12- Handelsman D.J., Turtle J.R. "Clinical trial of an aldose reductase inhibitor in diabetic neuropathy" Diabetes, 30, 459-64 (1981).

13- Costantino L., Rastelli G., Vianello P., Cignarella G., Barlocco D. "Diabetes complications and their potential prevention: Aldose reductase inhibition and other approaches" Med. Res. Rev., 19, 3-23 (1999).

14- Strumvoll M., Haring H-U. "Glitazones: Clinical effects and molecular mechanisms" Ann. Med., 34, 217-24 (2002).

15- Wilson T. M., Brown P. J., Sternbach D.D., Henke B.R. "The PPARs: from orphan receptors to drug discovery" J. Med. Chem., 43, 527-50 (2000).

16- Werner A. L., Travaglini M. T. "A Review of rosiglitazone in type 2 diabetes mellitus" Pharmacotherapy, 21, 1082-99 (2001).

17- Costantino L., Rastelli G., Cignarella G., Vianello P., Barlocco D. "New aldose reductase inhibitors as potential agents for the prevention of long-term diabetic complications" Exp. Opin. Ther. Pat., 7, 843-58 (1997).

18- Bozdağ-Dündar O., Ceylan-Ünlüsoy M., Verspohl E.J., Ertan R. "Synthesis and antidiabetic activity of novel 2,4-thiazolidinedione derivatives containing a thiazole ring" Arzneim. Forsch. Drug Res., 56 (9), 621-25 (2006).

19- Bradford M.M. "A Rapid and sensitive method for the quantitation of microgram quantities of protein utilizing the principle of protein-dye binding" Anal Biochem., 72, 24854 (1976).

20- Cerelli K.J., Curtis D.L., Dunn J.P., Nelson P.H., Peak T.M., Waterbury L.D. "Antiinflammatory and aldose reductase inhibitory activity of some tricyclic arylacetic acids" J. Med. Chem., 29, $2347-51$ (1986).

21- Ares J.J., Kador P.F., Miller D.D. "Synthesis and biological evaluation of irreversible inhibitors of aldose reductase" J Med Chem., 29, 2384-89 (1986). 
22- Urzhumtsev A., Tete-Favier F., Mitschler A., Barbanton J., Barth P., Urzhumtseva L., Biellmann J.F., Podjarny A., Moras D. “A 'specificity' pocket inferred from the crystal structures of the complexes of aldose reductase with the pharmaceutically important inhibitors tolrestat and sorbinil" Structure 5, 601-12 (1997).

23- Lee Y.S., Chen Z., Kador P.F. "Molecular modeling studies of the binding modes of aldose reductase inhibitors at the active site of human aldose reductase" Bioorg. Med. Chem., 6, 1811-19 (1998). 